\title{
Quality of life and depressive symptoms among caregivers and drug dependent people ${ }^{1}$
}

\author{
Samira Reschetti Marcon² \\ Elizete Aparecida Rubira ${ }^{2}$ \\ Mariano Martinez Espinosa ${ }^{3}$ \\ Dulce Aparecida Barbosa ${ }^{4}$
}

\begin{abstract}
The aim of this study was to evaluate the quality of life and the presence of depressive symptoms among the caregivers and drug dependent people of the CAPSad. This is a cross-sectional study, with 109 users of four Psychosocial Care Centers for alcohol and other drugs of Mato Grosso and their caregivers, using the instruments: Medical Outcomes Studies 36 (SF-36), Beck Depression Inventory (BDI) and a sociodemographic variables questionnaire. The QoL of the caregivers in the domains functional capacity, physical aspect, pain and vitality were more affected when compared to the users. A strong correlation between QoL and depressive symptoms was found in both groups. The comparisons performed demonstrate a compromise in the quality of life of both, with the group of caregivers most affected, confirming the situation of drug dependence as an important factor in the perception of the caregiver regarding their quality of life.
\end{abstract}

Descriptors: Quality of Life; Depression; Family Relations; Substance use Disorders.

\footnotetext{
${ }^{1}$ Apoyo financiero de la Coordenação de Aperfeiçoamento de Pessoal de Nível Superior (CAPES), proceso nº CAA/Dinter/17-10/2006, y de la Fundação de Amparo à Pesquisa do Estado de Mato Grosso (FAPEMAT), proceso no 014/08.

${ }^{2}$ RN, Ph.D. in Health Sciences, Adjunct Professor, Departamento de Enfermagem, Universidade Federal de Mato Grosso, Cuiabá, MT, Brazil. E-mail: Samira - samira.marcon@gmail.com, Elizete - earubira@gmail.com.

${ }^{3}$ Statistician, Post-doctoral in Reliability, Adjunct Professor, Departamento de Estatística, Universidade Federal Mato Grosso, Cuiabá, MT, Brazil. E-mail: marianomphd@gmail.com.

${ }^{4}$ RN, Post-doctoral in Nephrology, Adjunct Professor, Escola Paulista de Enfermagem, Universidade Federal de São Paulo, SP, Brazil. E-mail: dulce.barbosa@unifesp.br.
}

Corresponding Author:

Dulce Aparecida Barbosa

Universidade Federal de São Paulo. Escola Paulista de Enfermagem

Rua Napoleão de Barros, 754

Vila Clementino

CEP: 04024-002, São Paulo, SP, Brasil

E-mail: dulce.barbosa@unifesp.br 


\section{Qualidade de vida e sintomas depressivos entre cuidadores e dependentes de drogas}

O objetivo deste estudo foi avaliar a qualidade de vida e a presença de sintomas depressivos entre cuidadores e dependentes de drogas, dos CAPSad. Foi utilizado, como método, o estudo transversal, com 109 usuários de quatro Centros de Atenção Psicossocial - Álcool e Drogas, de Mato Grosso, e seus cuidadores, aplicando-se os instrumentos: Medical Outcomes Studies 36 (SF-36), inventário de depressão de Beck (BDI) e variáveis sociodemográficas. Constatou-se, pelos resultados, que a qualidade de vida (QV) dos cuidadores, nos domínios capacidade funcional, aspecto físico, dor e vitalidade, estava mais afetada, quando comparada aos usuários. Encontrou-se forte correlação entre QV e sintomas depressivos nos dois grupos. Conclui-se que as comparações realizadas demonstram comprometimento da qualidade de vida de ambos, sendo essa mais afetada no grupo de cuidadores, confirmando a situação de dependência de drogas como importante interveniente na percepção do cuidador, quanto à sua qualidade de vida.

Descritores: Qualidade de Vida; Depressão; Relações Familiares; Transtornos Relacionados ao uso de Substâncias.

\section{Calidad de vida y los síntomas depresivos en cuidadores y los adictos a las drogas}

Este estudio tuvo por objetivo evaluar la calidad de vida y los síntomas depresivos en cuidadores y adictos a drogas. Se trata de un estudio transversal en 109 usuarios y sus cuidadores en cuatro Centros de Atención Psicosocial de alcohol y otras drogas en el estado de Mato Grosso. Se aplicaron los instrumentos: Medical Outcomes Studies 36 (SF-36), Inventario de Depresión de Beck (BDI) y sociodemográficos. Se encontró que la calidad de vida de los cuidadores en los dominios de funcionamiento físico, dolor y vitalidad fueron más afectados en comparación a los usuarios. Se obtuvo una fuerte correlación entre la calidad de vida y los síntomas depresivos en ambos grupos. Las comparaciones demuestran que la calidad de vida del cuidador y del usuario están comprometidas, siendo que la más afectada corresponde al grupo de cuidadores, lo que confirma la situación de la dependencia de drogas como un actor importante en la percepción del cuidador sobre su calidad de vida.

Descriptores: Calidad de Vida; Depresión; Relaciones Familiares; Los Trastornos Relacionados con el Consumo de Sustancias.

\section{Introduction}

The literature has widely discussed the collective and/or individual consequences of drug dependence on society ${ }^{(1-3)}$, where collectively the family is the first to be affected in their functional and organizational dynamics(1). Thus, studies have provided information regarding the problems faced by the families of drug dependent people, faced with situations generated by the use, causing disagreement and fragilization in the interpersonal relationships ${ }^{(1-3)}$. These situations are revealed by feelings more directly linked to the emotional context, such as ambiguity, impotency, anxiety, fear, guilt, deception, frustration, depression, and other problems related to the routine situations of everyday life. Among other losses, the distancing from friends and the reduction of social activities with a consequent impairment of the quality of life ( $Q \circ L)$, is experienced by both the family and the drug dependent person $^{(1-2)}$ 
In the presence of dependence, the whole family structure can be shaken, however, the family members suffer varying degrees of closeness and distancing, faced with the negative impacts of this behavior. Commonly in the family, a member assumes the role of caregiver(2), being the person most directly linked to the care and/ or emotionally to person dependent on the drug(3), a condition that not only directly affects their QoL, but also predisposes them to the emergence of depressive symptoms ${ }^{(4)}$.

A study with family members of drug dependent people showed an increase in the risk of the emergence of mental disorders in $58.0 \%$ of the spouses, and a greater frequency of physical assaults, deaths of family members and involvement with the police in those homes $^{(4)}$. In relation to the user, in the last decade, the co-occurrence of mental disorders and drug dependence has been widely recognized in the psychiatric clinic(5). A national epidemiological survey of alcohol-related conditions, the National Epidemiologic Survey on Alcohol and Related Conditions (NESARC), among adults of the general population in the United States of America, showed a $20.0 \%$ prevalence of mood disorders and an $18 \%$ prevalence of anxiety disorders in individuals that use psychoactive substances(6).

The relationship between quality of life and the presence of depressive symptoms, has been investigated, mostly in the North American literature, which focus on intravenous drug users, users in substitution therapy (methadone), or on their family members separately (7-8), with no comparative studies with this population being encountered. In Brazil, few studies exist that address the theme of QoL in drug dependent people and, among these, many are directed toward the population of alcohol users ${ }^{(2,9)}$.

Currently, national policies aimed at drug dependence advocate community care for the user, making the family an important ally in the recovery process and in the improvement of the conditions of quality of life ${ }^{(10)}$. However, despite the need for participation and responsibility of the family members in the therapeutic process, the services that attend this clientele often focus on care for the users, relegating the caregivers to a secondary care, not valorizing their need for care and support(2). From this, the question can be asked, how does the quality of life of the caregivers compare to that of the drug dependent people?

Thus, considering the paucity of international and national data concerning the theme and the care policy that views the family as the object of care, this study contributes to the understanding of this population and provides information that can support the planning of interventions in the clinical practice, aiming to minimize the individual and collective damage caused by drug dependence, resulting in an improved quality of life for the individuals involved. This study aims to evaluate the quality of life and presence of depressive symptoms among caregivers and drug dependent people.

\section{Materials and Method}

\section{Study design and site}

The cross-sectional study was developed in four Psychosocial Care Centers for alcohol and other drugs (CAPSad) in four municipalities of the State of Mato Grosso: Cuiabá/capital, Várzea Grande, Rondonópolis and Barra do Garças.

\section{Population and Sample}

The population consisted of 109 illicit drug users, regardless of the type of drug used, who were registered in the four CAPSad of TM and their respective caregivers $(n=109)$. In this study the caregiver was defined as, the family member or person that the user had as a reference or that was responsible for monitoring the treatment in the service. The sample was obtained by the method of stratified random sampling proportional to the population size, the method was used due to the fact that the CAPSad of the four municipalities had populations of different sizes. Thus, the mean number of users who were in treatment at CAPSad, in the four municipalities, in 2007 was considered. The mean number of users per month was also considered, as they could be in treatment for several months consecutively, in their respective municipalities. Thus, the sample size was 109 users, being 42 of Cuiabá, 32 of Várzea Grande, 20 of Rondonópolis and 15 of Barra do Garças. It should be noted that in determining this sample number a $95 \%$ confidence interval, an estimation error of 0.05 and a ratio of 0.5 were used.

\section{Inclusion criteria}

Being a user of illicit drugs, regardless of the type of drug used, with the possibility of licit drugs associated. Inclusion criteria for the caregiver, being a family member or person responsible for the treatment of the user in the CAPSad. 


\section{Exclusion criteria for the users and caregivers}

Individuals who did not have the cognitive conditions for the comprehension of the Terms of Consent, who refused to participate in the survey, who were less than 18 years of age and a caregiver who was a user of any type of drug licit and/or illicit.

\section{Data collection instruments}

Three instruments were used: a questionnaire created to collect the demographic and socioeconomic data of both groups, and information regarding the type of drugs used. The Medical Outcomes Study 36 Item Short-Form Health Survey ${ }^{(11)}$ : a multidimensional translated instrument adapted and validated in Brazil in 1997, comprising 36 items, divided into eight scales or domains: functional capacity (10 items); physical aspects (4 items); pain ( 2 items); general health status (5 items); vitality (4 items); social aspects (2 items); emotional aspects ( 3 items); and mental health ( 5 items). To evaluate the final results a score is given from zero (corresponding to the worst health status) to 100 (corresponding to the best health status). At the end a numerical value is assigned for each domain. Beck Depression Inventory (12): A self-assessment scale for depression consisting of 21 items to evaluate depressive symptoms and attitudes that reflect the current state of the individual: sadness, pessimism, sense of failure, lack or loss of satisfaction, feelings of guilt, sense of punishment, self-deprecation, self-accusation, suicidal thoughts, crying spells, irritability, isolation or social withdrawal, indecision, body image distortion, inhibition to work, sleep disturbances, fatigue, loss of appetite, weight loss, somatic preoccupation and decreased libido. Each item is covered by four statements $(0,1,2$ or 3 ). More than one answer can be obtained for each question, with the alternative of greater value being considered. Depending on the nature of the sample there are different cutoff points. The cutoff point used was $<15=$ normal or mild depression, $16-20=$ dysphoria and $>20=$ depression.

\section{Data collection procedure}

For the data collection four nominal lists of the users registered in the 4 CAPSad were constructed. Next, a random selection was performed for the composition of the sample, generating a final list. The components of the list were informed about the purpose of the study, and permission to interview their family members was requested. The interviews were scheduled in advance and carried out individually in the service, with a duration of 40 to 50 minutes, for both groups. As well as the main researcher, a previously trained student of the Nursing Graduation Course participated in the collection. The data collection period was from August 2008 to September 2009.

\section{Ethical aspects}

This study was preceded by the approval by the Research Ethics Committee of the Federal University of São Paulo under protocol No. 0556/07 and signature of the Terms of Free Prior Informed Consent. All the participants were informed about their rights, according to Resolution 196/96 of the National Research Council.

\section{Statistical analysis}

For the comparison of the sample data descriptive and inferential analyses were performed. Among the qualitative variables the values of the absolute frequencies ( $n$ ) and percentages (\%) were used. For the quantitative variables, the means, standard deviations and standard error of the mean were considered. In the comparison between the users and the caregivers the Spearman's correlation coefficient was used between the BDI and the mean scores of SF36, with a significance level of $\alpha=0,05$. The statistical software used was SPSS (Statistical Package for the Social Sciences), version 15.0 and MINITAB version 15.

\section{Results}

Table 1 - Sociodemographic characteristics and depressive symptoms of the caregivers and users of the CAPSad of the State of Mato Grosso, Brazil, 2009

\begin{tabular}{lccc}
\hline & Variable & $\begin{array}{c}\text { Caregiver } \\
(\mathbf{n}=109)\end{array}$ & $\begin{array}{c}\text { User } \\
(\mathbf{n}=109)\end{array}$ \\
\hline Gender $\mathrm{n}(\%)$ & & & $\mathbf{p}$-value \\
Male & $10(9.2)$ & $92(84.4)$ & $<0.001$ \\
Female & $99(90.8)$ & $17(15.6)$ & $<0.001$
\end{tabular}


Table 1 - (continuation)

\begin{tabular}{|c|c|c|c|}
\hline Variable & $\begin{array}{c}\text { Caregiver } \\
(n=109)\end{array}$ & $\begin{array}{c}\text { User } \\
(n=109)\end{array}$ & p-value \\
\hline \multicolumn{4}{|l|}{ Ethnicity } \\
\hline White & $44(40.4)$ & $48(44.0)$ & 0.583 \\
\hline Non-white & $65(59.6)$ & $61(56.0)$ & 0.583 \\
\hline \multicolumn{4}{|l|}{ Marital status } \\
\hline Single & $34(31.2)$ & $71(65.1)$ & $<0.001$ \\
\hline Married & $75(68.8)$ & $38(34.9)$ & $<0.001$ \\
\hline \multicolumn{4}{|l|}{ Occupation } \\
\hline Have & $84(77.1)$ & $72(66.1)$ & 0.070 \\
\hline Do not have & $25(22.9)$ & 37 (33.9) & 0.070 \\
\hline \multicolumn{4}{|l|}{ Educational level } \\
\hline Illiterate & $10(9.2)$ & $0(0.0)$ & 0.002 \\
\hline Incomplete elementary education & $30(27.5)$ & $30(27.5)$ & 1.000 \\
\hline Complete elementary education & $24(22.0)$ & $46(42.2)$ & 0.001 \\
\hline Complete high school & $34(31.2)$ & $30(27.5)$ & 0.552 \\
\hline Complete further education & $11(10.1)$ & $3(2.8)$ & 0.050 \\
\hline Age $(\bar{x} \pm D P)$ & $47.6 \pm 13.8$ & $29.8 \pm 7.8$ & $<0.001$ \\
\hline Income $(\bar{x} \pm D P)$ & $R \$ 780.00 \pm R \$ 1509.00$ & $\mathrm{R} \$ 464.20 \pm \mathrm{R} \$ 492.80$ & 0.034 \\
\hline \multicolumn{4}{|l|}{ Depressive symptoms } \\
\hline Depression & $26(23.9)$ & $41(37.6)$ & 0.026 \\
\hline Dysphoria & $14(12.8)$ & $14(12.8)$ & 1.000 \\
\hline Normal & 69 (63.3) & $54(49.6)$ & 0.039 \\
\hline
\end{tabular}

Table 1 indicates that for the caregivers the variables gender - female, marital status - married, educated level - illiterate and complete further education, mean age and income were higher, with statistically significant differences in relation to the users. For the users the male gender, single, and complete elementary education were statistically significant in relation to the caregivers $(p<0.001)$. Regarding the presence of depressive symptoms, the scores were highest for the users compared to the caregivers $(p=0.026)$.

Table 2 - Comparison between mean scores of the SF36 domains of the caregivers and users of the CAPSad of the State of Mato Grosso, Brazil, 2009

\begin{tabular}{lccc}
\hline \multicolumn{1}{c}{ SF36 domains } & $\begin{array}{c}\text { Caregiver } \\
(\mathbf{n = 1 0 9 )}\end{array}$ & $\begin{array}{c}\text { User } \\
(\mathbf{n}=109)\end{array}$ & $p$-value \\
\hline Functional capacity & $69.8 \pm 2.3$ & $86.5 \pm 1.6$ & $<0.001$ \\
Physical aspect & $56.0 \pm 3.8$ & $66.1 \pm 3.3$ & 0.047 \\
Pain & $54.1 \pm 2.4$ & $62.2 \pm 2.7$ & 0.025 \\
General health status & $61.8 \pm 2.1$ & $65.6 \pm 2.0$ & 0.194 \\
Vitality & $52.8 \pm 2.3$ & $66.2 \pm 2.2$ & $<0.001$ \\
Social aspects & $62.4 \pm 2.4$ & $60.7 \pm 2.8$ & 0.653 \\
Emotional aspects & $44.6 \pm 4.0$ & $44.3 \pm 4.0$ & 0.955 \\
Mental health & $55.3 \pm 2.4$ & $60.2 \pm 2.2$ & 0.133 \\
\hline
\end{tabular}

Table 2 shows that the scores of the caregivers in the domains functional capacity $(p<0.001)$, physical aspect $(p=0.047)$, pain $(p=0.025)$ and vitality $(p<0.001)$ were significantly lower when compared with the scores of the users.

Table 3 - Comparison of the BDI and the mean scores of the SF36, between the caregivers and users of the CAPSad of the State of Mato Grosso, Brazil, using the Spearman correlation coefficient. 2009

\begin{tabular}{lcc}
\hline \multicolumn{1}{c}{ Dimension } & $\begin{array}{c}\text { Caregiver } \\
\text { Spearman's correlation } \\
\text { coefficient }(\rho)\end{array}$ & $\begin{array}{c}\text { User } \\
\text { Spearman's correlation } \\
\text { coefficient }(\rho)\end{array}$ \\
\hline $\begin{array}{l}\text { Functional } \\
\text { capacity }\end{array}$ & -0.421 & -0.463 \\
Physical aspect & -0.430 & -0.465 \\
Pain & -0.442 & -0.446 \\
General health & -0.508 & -0.557 \\
status & -0.632 & -0.596 \\
Vitality & -0.517 & -0.541 \\
Social aspects & -0.535 & -0.301 \\
Emotional & -0.712 & -0.714 \\
aspects & & \\
Mental health & &
\end{tabular}


In Table 3 it can be observed that the majority of the correlation coefficients of the caregivers were lower than the coefficients of the users, with the exception of vitality and emotional aspects that were higher, however, without being statistically significant. It should be highlighted that the significance of all the correlations between the BDI and the SF36 were lower than 0.001 ( $p$ $\leq 0.001$ ), for both groups.

\section{Discussion}

In relation to the sociodemographic variables, in the group of caregivers there was a greater predominance of females compared with the group of users. This finding is justified because the role of caregiver is often delegated to women, specifically the wife and/or family member. A study with caregivers of psychiatric patients evidenced in its sample $80.0 \%$ of women caregivers $^{(13)}$. Another study, which investigating the impact of alcohol abuse in the family, found a majority of females caregivers, and among these wives ${ }^{(2)}$, these characteristics were also found in caregivers of people with chronic diseases(14-15). In this study, the results reaffirm the findings of the literature and reflect the tradition of caring, relegating the responsibility for the care of the sick family member to the woman(2). The high proportion of male users confirms the tendency of a strong presence of this gender in the services of care for drug dependent people. Studies developed with this population have demonstrated that men use illicit drugs more in relation to women, and accredit being male as a risk factor for drug dependence ${ }^{(9,16)}$.

Concerning the marital status variable, there was a statistically significant difference between the two groups, where $68.8 \%$ of caregivers reported living with a partner, while among the users, the proportion was $31.2 \%$, i.e. the large majority were single. Regarding the educational level $(p<0.001)$ the caregivers presented higher percentages of further education in relation to users, probably contributing to the higher monetary income of the first group. Considering that $42.2 \%$ of the users had only completed elementary education, it is believed that the insertion in the labor market becomes more difficult and is compounded by the drug use and its repercussions. Although the majority of the users reported some type of occupation, the low mean monthly income reflects the inconsistency of the work activities, a fact observed in the interviews, where many reported not having a formal employment contract.
The mean age of the caregivers was higher in relation to the users. In this study, the mean age of the caregivers was slightly lower compared to other studies with caregivers ${ }^{(15,17)}$. A fact also found among the users, where the mean age was lower compared with other studies conducted among drug dependent people ${ }^{(7,18)}$.

The presence of depressive symptoms among the caregivers was lower when compared with a study performed with caregivers of HIV infected patients, where $50.0 \%$ presented depressive symptoms ${ }^{(18)}$. Another study with wives of alcohol dependent men, verified a high frequency of psychological symptoms (70.9\%), followed by physical symptoms (19.3\%) and physical and psychological symptoms together (3.2\%), these findings demonstrate that the participants were found to be more psychologically vulnerable(19).

Regarding the users, $37.6 \%$ presented a BDI score suggestive of signs of depression and $12.8 \%$ of dysphoria with the mean score $16.6 \pm 11$. In a study with users in a dependence treatment program in the U.S.A., the findings showed a mean BDI score of $14.9 \pm 0.6$, where $58.0 \%$ of the sample presented depressive symptoms ${ }^{(8)}$. The investigation of the association between depression and dependence on illicit drugs among the population of Latin America, showed that $58.4 \%$ of illicit drug users presented depression according to the DSM IV criteria(16). A study conducted with HIV-infected individuals who used illicit drugs, showed that $69.0 \%$ of the patients obtained scores suggestive of depression(17), a higher percentage to that found in the present study. In the comparison between the caregivers and users of this study, there was a greater proportion of depressive symptoms among the users, which may reflect the comorbidity associated with drug dependence. Drug dependence has been demonstrated as a risk factor for developing depression and other mental disorders ${ }^{(6)}$.

Regarding the quality of life, it can be seen that the mean scores of the caregivers in the domains functional capacity, physical aspect, pain and vitality were lower when compared with the scores of the users. While the quality of life has been evaluated in different populations of caregivers of chronic disease sufferers ${ }^{(13-15)}$, studies are scarce regarding drug dependence and almost totally directed toward the caregivers of alcohol dependent people(1-2,19), excluding the caregivers of illicit drug users that, however, have a compromised quality of life according to these studies ${ }^{(1,20)}$. Drug dependence represents a dysfunction or inadequacy for the activities of quotidian life, therefore, the caregivers spend most of their lives in an attempt to regain the family stability ${ }^{(21)}$. 
The majority of the wife and/or mothers caregivers of drug dependent people are often obliged to manage the house, children and professional life alone. They suffer from a lack of information, inability and feelings of frustration for failing to help in the recovery from the dependence of the partner/son, generating intense feelings of guilt(21), a situation that causes physical and emotional instability directly interfering with the quality of life. Among the caregivers in this study, the scores were much lower when compared with other caregivers of chronic disease sufferers using the same instrument ${ }^{(14-15)}$. A possible hypothesis for this finding refers to the fact that, concerning drug dependence, to care for the family member can be a negotiated choice or not, or even denied. The relationship of care is not always a relationship of solidarity and selflessness, but also a practice of obligation, where this option leads to suffering(1). The caregiver experiences fatigue, depression and impotence more directly, to the extent that they follow the relapses of the dependent person. These generate expectations situated in the discreditable/ discredited dimension, a feeling the consequence of which is an extreme overload, compounded by the loss of hope and anger due to the feeling of impotence to reverse the situation, additionally resulting in the impairment of QoL and in some cases the emergence of depression ${ }^{(1)}$.

Although the users had higher QoL scores than their caregivers, in relation to the population of chronically ill people their scores were lower(15). However, when compared with patients in the Gastroenterology Outpatient Clinic and Outpatient Clinic Specializing in the Treatment of Drug Dependence, the findings of the present study showed slightly higher scores in all the dimensions of the SF36(9). The scores were also higher when compared to a study with alcoholics who sought care in a Reference Center in the city of Porto Alegre RS, and these authors point out that the higher the degree of consumption of alcohol, the greater the impairment in the quality of life(19).

The comparison of the BDI and the mean scores of the SF-36 domains between the users and caregivers using the Spearman's correlation coefficient $(\rho)$ showed that all the correlations were statistically significant $(p \leq 0.001)$, both for the caregivers and for the users, and that in both groups the mental health and vitality domains were the most affected when correlated with the depressive symptoms. Thus, it is clear that the presence of depressive symptoms compromises the quality of life for both groups.
Considering the current care model, in which the family is constituted as a health unit for its members, the healthcare network should be configured to provide support for the caregivers and users, with an emphasis on the emotional, psychological and social aspects, and for this type of approach, the measurement of quality of life can be used as a valuable resource ${ }^{(10)}$.

\section{Conclusions}

The results obtained in relation to the user and their caregiver regarding the compromise in the quality of life, the presence of depressive symptoms and the strong correlation between the QoL and the BDI, draws attention to the need for interventions with this population, through nursing actions integrated with the multidisciplinary team such as: clarification for the family regarding drug dependence, performance of group work with caregivers in order to exchange experiences and to stimulate discussion of the difficulties and possibilities of living with the problem, as well as community activities that seek integration between drug dependent people and their caregivers.

Considering the paucity of studies related to this theme, the need for further studies with this populational group is highlighted, in order to investigate the possible factors involved in the compromise of the quality of life and consequently in the appearance of depressive symptoms or other psychological disorders arising from the interaction of the caregiver/drug dependent person.

\section{References}

1. Miranda FAN, Simpson CA, Azevedo DM, Costa SS. O impacto negativo dos transtornos do uso e abuso do álcool na convivência familiar. Rev Eletr Enferm. [periódico na Internet]. 2006;8(2):222-32. Disponível em: http:// www.fen.ufg.br/revista/revista8_2/v8n2a07.htm.

2. Gonçalves JRL, Galera SAF. Assistência ao familiar cuidador em convívio com o alcoolista, por meio da técnica de solução de problemas. Rev. Latino-Am. Enfermagem. maio-jun 2010 May-Jun;18(Spec):543-9. 3. Schenker M, Minayo MCS. A importância da família no tratamento do uso abusivo de drogas: uma revisão da literatura. Cad Saúde Pública. 2004;20(3):649-59.

4. Figlie N, Fontes A, Mores E, Payá R. Filhos de dependentes químicos com fatores de risco biopsicossociais: necessitam de um olhar especial? Rev Psiquiatr Clín. 2004;31(2):53-62. 
5. Zaleski M, Laranjeira RR, Marques ACPR, Ratto L, Romano M, Alves HNP, et al . Diretrizes da Associação Brasileira de Estudos do Álcool e outras Drogas (ABEAD) para o diagnóstico e tratamento de comorbidades psiquiátricas e dependência de álcool e outras substâncias. Rev Bras Psiquiatr. 2006;28(2):142-8.

6. Grant BF, Frederick FS, Dawson A, Chou P, Dufour $\mathrm{MC}$, Compton $\mathrm{W}$, et al. Prevalence and co-occurrence of substance use disorders and independent mood and anxiety disorders. Arch Gen Psychiatr. 2004;6:807-16.

7. Costenbader EC, Zule W, Coomes CM. The impact of illicit drug use and harmful drinking on quality of life among injection drug users at high risk for hepatitis $C$ infection. Drug Alcohol Depend. 2007;89(2-3):251-8.

8. Coviello DM, Alterman AI, Cacciola JS, Rutherford MJ, Zanis DA. The role of family history in addiction severity and tratament response. J Subst Abuse Treat. 2004;26:1-11.

9. Payá, R, Figlie NB, Turisco JL e Ronaldo L. Como é a qualidade de vida dos dependentes de álcool? J Bras Psiquiatr. 2002;51(1):39-45.

10. Ministério da Saúde (BR). Secretaria de atenção à saúde. A política do ministério para atenção integral a usuários de álcool e outras drogas. Brasília: Ministério da Saúde; 2004.

11. Ciconelli RM, Ferraz MB, Santos W, Meinão I, Quaresma MR. Tradução para a língua portuguesa e validação do questionário genérico de avaliação da qualidade de vida SF-36 (Brasil SF-36). Rev Bras Reumatol. 1999;39(3):143-50.

12. Gorestein C, Andrade L. Inventário de depressão de Beck: propriedades psicométricas da versão em português. Rev Psiquiatr Clín. 1998;25(5 ed esp):245-50.

13. Barroso SM, Bandeira M, Nascimento E. Sobrecarga de familiares de pacientes psiquiátricos atendidos na rede pública. Rev Psiquiatr Clín. 2007;34(6):270-7.

14. Pinto MF, Barbosa DA, Ferreti CEdeL, Souza LFdeS, Fram DS, Belasco AGS. Qualidade de vida de cuidadores de idosos com doença de Alzheimer. Acta Paul Enferm. 2009;22(5):652-7.

15. Belasco A, Barbosa D, Bettencourt AR, Diccini S, Sesso R. Quality of life of family caregivers of elderly patients on hemodialysis and peritoneal dialysis. Am J Kidney Dis. 2006;48(6):955-63.

16. Ferigolo $M$, Stein AT, Fuchs FD, Barros HMT. Influence of depression and early adverse experiences on illicit drug dependence: a case-control study. Rev Bras Psiquiatr. 2009;31(2):106-13.
17. Pirraglia PA, Bishop D, Herman DS, Trisvan E, Lopez RA, Torgersen CS, et al. Caregiver burden and depression among informal caregivers HIV-infected individuals. J Gen Intern Med. 2005;20:510-4.

18. Lahmek P, Berlin I, Michel L, Berghout C, Meunier $\mathrm{N}$, Aubin $\mathrm{HJ}$. Determinants of improvement in quality of life of alcohol-dependent patients during na inpatient withdrawal programme. Int Med Sci. 2009;6(4):160-7. 19. Lima RA dos S, Amazonas MCL de A, Motta JAG. Incidência de stress e fontes estressoras em esposas de portadores da síndrome de dependência de álcool. Estud Psicol. 2007;24(4):431-9.

20. Sattar SP, Padala PR, McArthur-Miller D, Roccaforte WH, Wengel SP, Burke WJ. Impacto of problem alcohol use on patient behavior and caregiver burden in a geriatric assessment clinic. J Geriatr Psychiatry Neurol. 2007;20(2):120-7.

21. Aragão ATM, Milagres E, Figlie NB. Qualidade de vida e desesperança em familiares de dependentes químicos. PsicoUSF. 2009;14(1):117-23.
Received: May $7^{\text {th }} 2011$ Accepted: Jan. 6th 2012 